\title{
INVESTIGATING THE QUALITY OF DURUM WHEAT LANDRACES AND DETERMINATION OF PARENTS TO USE IN BREEDING PROGRAMS
}

\author{
KENDAL, E. $.^{*}-$ EREN, A. ${ }^{1}-$ DOĞAN, Y $.{ }^{1}-$ ORAL, E. ${ }^{2}-$ KOYUNCU, M. ${ }^{3}$ \\ ${ }^{I}$ Department of Seed Production, Kiziltepe Vocational Training High School, Mardin Artuklu \\ University, 21500 Klzlltepe, Mardin, Turkey \\ ${ }^{2}$ Department of Field Crops, Faculty of Agriculture, Van Yüzüncü Yıl University, Van, Turkey \\ ${ }^{3}$ Department Engineering of Food, Karamanoğlu Mehmetbey University, Karaman, Turkey \\ *Corresponding author \\ e-mail: enver21_1@hotmail.com
}

(Received $15^{\text {th }}$ Feb 2019; accepted $21^{\text {st }}$ Mar 2019)

\begin{abstract}
The study was conducted to evaluate the quality of durum wheat grain. For this reason, genetic resources are crucial for the identification of parents and the enrichment of the gene pool that can be used in the development of new varieties for better nutrition of people. For this purpose, 131 populations of landraces, 9 promising line and 5 new varieties were used. The experiment was set up in randomized blocks with 7 replications, according to the augmented (increased) experimental design in 2015-2016 growing season. In the study, we examined total nitrogen content, protein ratio, CIE (Commission Internationale Eclairage) wheat color analysis ( $\mathrm{L}^{*}$ brightness, $\mathrm{b}^{*}$ jaundice, $\mathrm{a}^{*}$ redness) of 145 genotypes of durum wheat seeds. According to analysis of variance, highly significant differences $(\mathrm{P}<0.05$ or $\mathrm{P}<0.01)$ were determined for total nitrogen, protein content and CIE $\mathrm{L}^{*}$ value, while differences were not significant for $b^{*}$ value and $a^{*}$ value. The superiority of the genotypes was determined by the first two principal components (IPC1 (principle component) and IPC2) in order to create a two-dimensional GT biplot. The sum squares of the first two components were accounted by $45.34 \%$ (PC1) and $40.03 \%$ (PC2) for genotypes. The GT (genotype $\mathrm{x}$ trait) biplot indicated that 9 (nine) sectors occurred among genotypes and quality parameters. On the other hand, three groups occurred among the quality parameters based on the genotypes. The scatter plot demonstrated that there is a high correlation between $b^{*}$ jaundice, and $\mathrm{a}^{*}$ redness. The results showed that cultivars and more landraces have general adaptability for all quality parameters, while some genotypes (G79, G78), (G22, G102), (G3) and (G121, G5) showed specific adaptation for $\mathrm{N}$ (nitrogen), PC (protein content) and $\mathrm{L}^{*}, \mathrm{a}^{*}$ and $\mathrm{b}^{*}$ values, respectively. According to the biplot techniques, G36 came forward with the N, P and a* value and desirable landraces, G5 for $b^{*}$ value, G30 stable line for all quality parameters, while (G128, G61) and the majority of promising lines (L4, L6) did not come forward with any quality parameters. The results of the study indicated that the majority of landraces can be used as parents to improve the quality of durum wheat varieties. The study indicated that GT biplot can be used to evaluate the genotypes graphically to select the best genotypes for parents to use in breeding programs.
\end{abstract}

Keywords: GT biplot, quality parameters, Southeastern Anatolia, Turkey

\section{Introduction}

Global biodiversity and plant genetic diversity compose of the genetic resources which are crucial for the identification of parents and the enrichment of the gene pool that can be used in the development of new varieties for better nutrition of people. For this reason, landraces are very important as genetic resources for identity of parents to improve gene pool and develop new quality varieties for better people's health. Nowadays, quality of durum wheat is most substantial for healthy fed in Middle East countries, because majority of people are fed from durum wheat product (bulghur, 
macaroni, bread). Therefore, landraces are considerable for breeding program of durum wheat, because most people care to use the healthy-products (bulghur, macaroni, and bread) of wheat. Upon domestication, it was estimated that initial diversity was reduced by $84 \%$ in durum wheat (Jaradat, 2013).

Turkey is located at a unique position from the view point of plant genetic diversity. Due to both in terms of environmental conditions and in terms of culture is very suitable for wheat cultivation. Turkey is one of the Centers of Origin of wheat and wheat has been grown around 8.5 million ha with production of around 20 million tons annually (http://www.tuik.gov.tr/PreHaberBultenleri.do?id; Karaman, 2019). The total 50\% of durum wheat is produced in Southeastern Anatolia region where is center (Karacadag) origin of durum wheat. Southeastern Anatolia region follows the Southeastern Taurus Mountains and the valley of the Tigris River. Frequency of durum wheat exceeds $60 \%$, with a high diversity of morph types dominated by murkiness (Morgounov et al., 2016).

The nutrient content of wheat grain can vary from genetic resources (landraces population, wild wheat, the orjin of cultivars) to regions and continents. Domestication and deep selecting in breeding progression significantly influenced to the depletion of nutritional content and in minimizing the genetic diversity of crops. An analysis of the nutritional value, especially micronutrients in the CIMMYT (International Maize and Wheat Improvement Center)-developed germplasm displayed that a declining trend in the micronutrient levels of the varieties (Velu et al., 2014; Pandey et al., 2016).

Nowadays, over three billion people suffer from "malnutrition", a locution used to define shortage of micronutrients (FAO, 2013). At the present time, nutrient shortcoming is a problem both common in developing countries, but extensive in developed countries where diet is mainly dependent on cereals. Therefore, the durum wheat program need to progressive revelation studies of nutritional in breeding. Throughout the last century, the input of high-yielding cultivars, led to the loss of genetic diversity. Wheat landraces are comprised of complex, variable, genetically dynamic and diverse populations, for both biotic, abiotic stresses in their environment and micro-macronutrient.

On the other hand, durum wheat breeding programs should have focuses on the develop of new varieties for high quality which are important for modern pasta and bulgur industry, because of changing consumption habits and undernourishment places where this is based on durum wheat. To achieve this goal, durum wheat landraces keeps its importance inside genetic diversity in Middle east and Southeastern Anatolia region. Because local durum wheat populations have adequate quality characteristics (nitrogen content, protein ratio, wheat color analysis ( $\mathrm{L}^{*}$ brightness, $\mathrm{b}^{*}$ jaundice, $\mathrm{a}^{*}$ redness) for the development of new varieties that can be used in the pasta and bulgur industries. For this reason, durum wheat breeders have recently given more importance to the durum wheat landraces in order to raise the quality criteria in durum wheat.

Among quality criteria seed quality is one of the important factor effecting plant growth, yield and nutrient uptake by the plants. For a good and healthy growing start seed quality is important. Seed quality is one of the best criteria for cereal productions and qualified seeds led to about 25 to 40 percent yield increase. During the early stage, plants meet their nutrient and energy demand from the reserves in their seeds mostly. So, huge nutrient stocks in the seeds are vitally important for plants to be able to survive their growth healthy (Erdal et al., 2017).

The aims of the present study were to assess the importance of the local durum of wheat landraces that are about to disappear in nature and constitute the source of the 
gene for durum wheat in terms of quality criteria to determine the parents which can be used in durum wheat breeding programs.

\section{Materials and methods}

\section{Plant material and experimental arrangement}

The study was conducted using a total of 131 populations of landraces; 9 promising landraces and 5 new varieties were used. The populations of landraces were collected from Southeastern Anatolia region of Turkey where is centers for origin of durum wheat. The cultivars are used registered by International Agricultural Research and Training Center during last decades. The varieties used in the study both have good quality criteria and very common cultivating in this region. The coordinate data of the used genotypes indicated in Table 1. The meteorological data showed in Figure 1. The map to overview of the areas of collected landraces of durum wheat presented in Figure 2.

Table 1. The coordinate of landraces which collected places Shout Eastern of Anatolia

\begin{tabular}{|c|c|c|c|c|c|c|c|}
\hline \multirow{2}{*}{ No } & \multirow{2}{*}{$\begin{array}{l}\text { Altitude } \\
\text { (m) }\end{array}$} & \multicolumn{2}{|c|}{ Coordinates } & \multirow{2}{*}{ No } & \multirow{2}{*}{ Altitude (m) } & \multicolumn{2}{|c|}{ Coordinates } \\
\hline & & $\mathbf{X}$ & $\mathbf{Y}$ & & & $\mathbf{X}$ & $\mathbf{Y}$ \\
\hline 1 & 803 & 596291 & 4222874 & 71 & 1016 & 634008 & 4301447 \\
\hline 2 & 710 & 596898 & 4221585 & 72 & 1090 & 584410 & 4293758 \\
\hline 3 & 700 & 599901 & 42209007 & 73 & 1283 & 485371 & 4269859 \\
\hline 4 & 709 & 599954 & $42 \quad 1682$ & 74 & 1348 & 485612 & 4270632 \\
\hline 5 & 735 & 600531 & 4222173 & 75 & 811 & 522958.63 & 4194028.75 \\
\hline 6 & 725 & 600386 & 4222039 & 76 & 715 & 519141.53 & 4193911.25 \\
\hline 7 & 687 & 598988 & 4218628 & 77 & 715 & 519141.53 & 4193911.25 \\
\hline 8 & 685 & 63610 & 4220816 & 78 & 762 & 519532.25 & 4191512.25 \\
\hline 9 & 703 & 605131 & 4222688 & 79 & 762 & 524911.00 & 4180531.50 \\
\hline 10 & 777 & 606500 & 4228778 & 80 & 668 & 513518.31 & 4150858.75 \\
\hline 11 & 838 & 606226 & 4231796 & 81 & 728 & 526140.69 & 4150528.00 \\
\hline 12 & 863 & 625538 & 4251067 & 82 & 925 & 664595.38 & 4146901.00 \\
\hline 13 & 872 & 626115 & 4251110 & 83 & 925 & 664595.38 & 4146901.00 \\
\hline 14 & 862 & 627655 & 4251196 & 84 & 925 & 664595.38 & 4146901.00 \\
\hline 15 & 884 & 619904 & 4251715 & 85 & 848 & 662635.94 & 4154887.00 \\
\hline 16 & 907 & 618144 & 4252344 & 86 & 828 & 662583.94 & 4156068.50 \\
\hline 17 & 910 & 614216 & 4251336 & 87 & 836 & 662792.13 & 4156608.25 \\
\hline 18 & 888 & 610797 & 4260263 & 88 & 1002 & 670122.88 & 4157678.03 \\
\hline 19 & 853 & 610396 & 4249353 & 89 & 1094 & 682464.10 & 4158560.50 \\
\hline 20 & 796 & 610891 & 4248325 & 90 & 1089 & 682464.10 & 4158560.50 \\
\hline 21 & 787 & 611954 & 4248357 & 91 & 978 & 692842.94 & 4148766.75 \\
\hline 22 & 785 & 611951 & 4248355 & 92 & 997 & 687266.91 & 4149245.25 \\
\hline 23 & 1064 & 650497 & 4237654 & 93 & 988 & 686129.00 & 4149423.25 \\
\hline 24 & 1050 & 650164 & 4237395 & 94 & 1094 & 679879.00 & 4146845.75 \\
\hline 25 & 679 & 681780 & 4237283 & 95 & 1069 & 675314.00 & 4143407.00 \\
\hline 26 & 681 & 681781 & 4237284 & 96 & 917 & 634.514 .94 & 4152010.25 \\
\hline
\end{tabular}




\begin{tabular}{|c|c|c|c|c|c|c|c|}
\hline 27 & 895 & 68456 & 4266685 & 97 & 1041 & 617647.80 & 4142738.75 \\
\hline 28 & 895 & 684652 & 4246867 & 98 & 950 & 708362.06 & 4135393.00 \\
\hline 29 & 897 & 683593 & 4249088 & 99 & 911 & 708190.01 & 4136542.20 \\
\hline 30 & 853 & 668840 & 4260416 & 100 & 882 & 708019.88 & 4137244.75 \\
\hline 31 & 786 & 594207 & 422878 & 101 & 921 & 707595.06 & 4141429.25 \\
\hline 32 & 837 & 594634 & 42275550 & 102 & 934 & 707360.75 & 4143376.50 \\
\hline 33 & 931 & 592344 & 4231601 & 103 & 965 & 70935.75 & 4150709.25 \\
\hline 34 & 873 & 588191 & 4241045.50 & 104 & 986 & 708496.50 & 4153507.00 \\
\hline 35 & 812 & 588895 & 4241660 & 105 & 990 & 708098.13 & 4154453.25 \\
\hline 36 & 865 & 635665 & 4253198.50 & 106 & 986 & 708146.00 & 4154610.50 \\
\hline 37 & 1025 & 636301 & 4259395 & 107 & 986 & 708146.00 & 4154610.50 \\
\hline 38 & 890 & 636017 & 4254531.50 & 108 & 723 & 715642.15 & 4227401.15 \\
\hline 39 & 876 & 650340.75 & 4258239.50 & 109 & 723 & 715642.15 & 4227401.15 \\
\hline 40 & 978 & 556997.56 & 4236808.00 & 110 & 573 & Unknown & Unknown \\
\hline 41 & 1032 & 555252.81 & 4236790.50 & 111 & 628 & 749524.25 & 4208746.00 \\
\hline 42 & 814 & 547904.19 & 4234858.50 & 112 & 970 & 760148.05 & 4204095.09 \\
\hline 43 & 862 & 541615.56 & 4232495.50 & 113 & 970 & 760148.05 & 4204095.09 \\
\hline 44 & 884 & 540057.13 & 4231857.50 & 114 & 496 & 753207.81 & 4191005.25 \\
\hline 45 & 677 & 541118.75 & 4224902.50 & 115 & 496 & 753207.81 & 4191005.25 \\
\hline 46 & 723 & 536671.00 & 4219466.00 & 116 & 462 & 749122.01 & 4187300.25 \\
\hline 47 & 729 & 496012 & 4195229 & 117 & 462 & 749122.01 & 4187300.25 \\
\hline 48 & 828 & 502219.75 & 4201199.50 & 118 & 461 & 748892.38 & 4186918.01 \\
\hline 49 & 805 & 502337.59 & 4201143.50 & 119 & 542 & 747895.05 & 4878340.50 \\
\hline 50 & 805 & 502337 & 4201143.50 & 120 & 723 & 754523.31 & 4177849.50 \\
\hline 51 & 755 & 502776.56 & 4202023.50 & 121 & 723 & 754523.31 & 4177849.50 \\
\hline 52 & 722 & 502318.59 & 4202746.00 & 122 & 787 & 759218.71 & 4175591.72 \\
\hline 53 & 1045 & 500979.00 & 4210611.50 & 123 & 841 & 759326.81 & 4176481.75 \\
\hline 54 & 925 & 498985.97 & 4210780.00 & 124 & 1003 & 239151.64 & 4170548.75 \\
\hline 55 & 1025 & 496297.66 & 4210493.50 & 125 & 1202 & 244929.83 & 4173425.00 \\
\hline 56 & 1032 & 496144.84 & 4210521.50 & 126 & 875 & 760055.31 & 415805.50 \\
\hline 57 & 1032 & 496144.84 & 421052.50 & 127 & 1005 & 756303.63 & 4155465.75 \\
\hline 58 & 1077 & 492395.16 & 4209038 & 128 & 792 & 756828.00 & 4153671.25 \\
\hline 59 & 890 & 488445.31 & 4207384.00 & 129 & 730 & 753644.69 & 415549.00 \\
\hline 60 & 819 & 449332.03 & 4204385.00 & 130 & 883 & 741775.94 & 4158370.25 \\
\hline 61 & 835 & 450771.00 & 4203501.50 & 131 & 896 & 738389.38 & 4158352.50 \\
\hline 62 & 858 & 452118.34 & 4203644.00 & 132 & 896 & 738389.38 & 4158352.50 \\
\hline 63 & 858 & 452118.34 & 4203644.00 & 133 & 978 & 727246.69 & 4155708.75 \\
\hline 64 & 893 & 458033 & 4203095 & 134 & 978 & 727246.69 & 4155708.75 \\
\hline 65 & 867 & 528384 & 4272667 & 135 & 978 & 727246.69 & 4155708.75 \\
\hline 66 & 862 & 546436 & 4274936 & 136 & 978 & 727246.69 & 4155708.75 \\
\hline 67 & 857 & 565288 & 4278407 & 137 & 978 & 727246.69 & 4155708.75 \\
\hline 68 & 1031 & 577881 & 4280381 & 138 & 951 & 724918.13 & 4154284.00 \\
\hline 69 & 1095 & 625437 & 4289576 & 139 & 951 & 724918.13 & 4154284.00 \\
\hline 70 & 1164 & 625998 & 4288948 & 140 & 951 & 724918.13 & 4154284.00 \\
\hline
\end{tabular}

Checks: 1-Artuklu, 2-Hasanbey, 3-Hasanbey, 4-Şahinbey, 5-Zühre. All control varieties released from GAP International Research and Training Center 


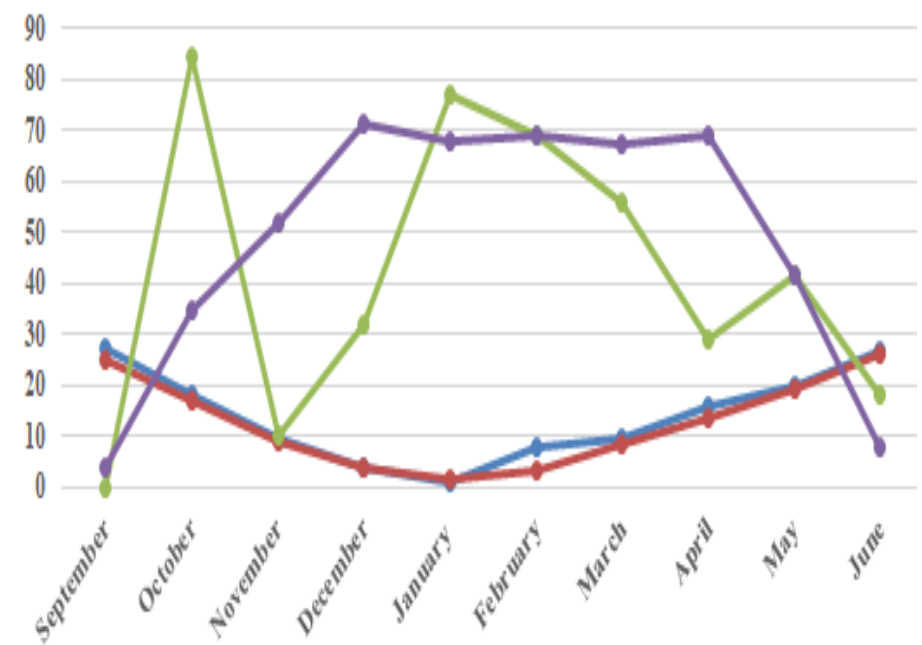

$\rightarrow$-Arerage of temperatures $(0 \mathrm{C})$ 2015-2016 $\rightarrow$-Arerage of temperatures(0C) Long-Term

Figure 1. The values of meteorological data of 2015-16 season and average of long term in research area

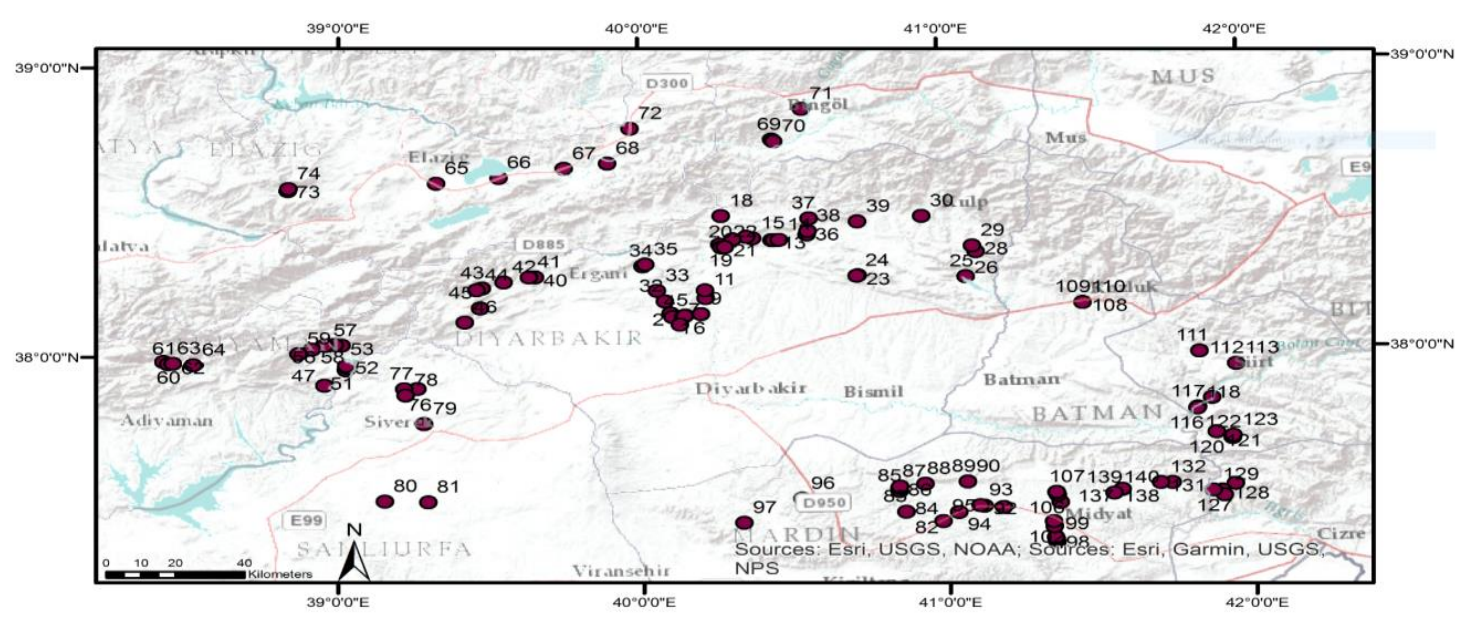

Figure 2. The map to overview of the areas of collected landraces of durum wheat used in the research

The experiment was set up in randomized blocks with 7 replications, according to the augmented (increased) experimental design in Diyarbakır conditions in 2015-2016 growing season. The seeding rates were 450 seeds $\mathrm{m}^{-2}$. Plot size was $0.4 \mathrm{~m}^{2}$ $(20 \mathrm{~cm} \times 1 \mathrm{~m})$ consisting of 2 rows spaced $20 \mathrm{~cm}$ apart. Sowings were made by hands. The fertilization rates for all plots were $60 \mathrm{~kg} \mathrm{~N} \mathrm{ha}^{-1}$ and $60 \mathrm{~kg} \mathrm{P} \mathrm{ha}^{-1}$ with sowing time and $60 \mathrm{~kg} \mathrm{~N} \mathrm{ha}^{-1}$ was applied to plots at the early stem elongation. Harvests were made using Hege 140 harvester.

In the study, we examined total nitrogen content, protein ratio, wheat color analysis ( $\mathrm{L}^{*}$ brightness, $\mathrm{b}^{*}$ jaundice, $\mathrm{a}^{*}$ redness) of 145 genotypes of durum wheat seeds. All analysis was done in the lab of Department Enginering Food of Karamanoğlu Mehmetbey University. 


\section{Total nitrogen content (N\%)}

Data were recorded for grain protein content. It was estimated from a random sample of $100 \mathrm{gm}$ of hand-threshed seeds of each genotype per samples. The seeds were milled and total Nitrogen percent (N\%) was determined by Kjeldahl method as described in the manual by Sertsu and Bakele (2000).

\section{Total protein content (\%)}

Data were recorded for grain protein content. It was estimated from a random sample of $100 \mathrm{gm}$ of hand-threshed seeds of each genotype per samples. The seeds were milled and total Nitrogen percent $(\mathrm{N} \%)$ was determined by Total nitrogen $(\mathrm{N})$ contents of the samples were measured using a nitrogen analyzer (Velp Scientifica, Dumas Nitrogen Analyzer - NDA 701, Italy) running on a Dumas incineration method (AACC Method 46-30) and protein contents calculated using a 5.7 nitrogen-protein conversion factor AACC, 2000). There is a linear relationship between protein ratio and total nitrogen (Nuttall et al., 2017).

\section{$L^{*}, a^{*}$ and $b^{*}$ color}

Wheat samples of $300-\mathrm{g}$ grain portions were cleaned and tempered overnight to $16.5 \%$ moisture and milled on a QC-109 laboratory mill into semolina as described by Petrova (1993). $\mathrm{L}^{*}$ and color $\left(\mathrm{a}^{*}, \mathrm{~b}^{*}\right)$ values were measured (AACC Method 14-22) using Hunter colorimetric (Color Flex A60-1010-615, Hunter Lab, VA, USA) of samples ground using a $1 \mathrm{~mm}$ size sieve (AACC, 2000). Yellow pigment content of wheat, semolina and pasta disc was determined according to ICC method 152 as $\beta$ carotene from a standard curve. Semolina color was measured by the CIE 1976 (Commission Internationale de l' Eclairage) $\mathrm{L}^{*} \mathrm{a}^{*} \mathrm{~b}^{*}$ color system. $\mathrm{L}^{*}$ indicates lightness, $\mathrm{a}^{*}$ represents redness, and $\mathrm{b}^{*}$ represents yellowness of color. The colors of semolina and flours are expressed using the $L^{*} a^{*} b^{*}$ color system. $L^{*}$ is a measure of brightness, it can ranges from 0 , completely non-reflective or black and 100 , perfect white or total reflection. Bread wheat flours have reading values around 90, while semolina has lower values. The $\mathrm{b}^{*}$ value is the blue-yellow chromaticity coordinate, it can go from -60 , pure blue, to +60 , pure yellow. Usual $b^{*}$ values for bread wheat flours are around 9.5. For semolina the higher the $b^{*}$ value the more yellowness. Good quality durum has $a b^{*}$ of approx. 27.3 or more. The $b^{*}$ value is the red-green coordinate.

\section{Statistical analyses}

The data obtained from the study related the investigated quality parameters were analyzed by using the JMP 5.0.1 statistical software package (SAS Institute, 2002), and the differences between means were compared using a least significant difference (LSD) test at the 0.05 probability level (Steel and Torrie, 1980). GT biplot analyses were carried out using GT biplot software to assess quality parameters (Yan and Thinker, 2006). In multi-traits (MT) for genotypes, biplots were constructed by plotting the first two principal components (PC1 and PC2) derived from centered quality criteria data to singular value separation. Also, with the GT biplot analysis graphs in the study: It was aimed at revealing relation among examined traits and genotypes means by scatter plot (Fig. 3), and grouped quality parameters and performance of each genotype at each trait (Fig. 4), which-won-where of sector analysis (Fig. 5), the stable and high 
performance of genotypes quality parameters by ranking model (Fig. 6), compare the desirable genotypes to ideal center on parameters by comparison model (Fig. 7).

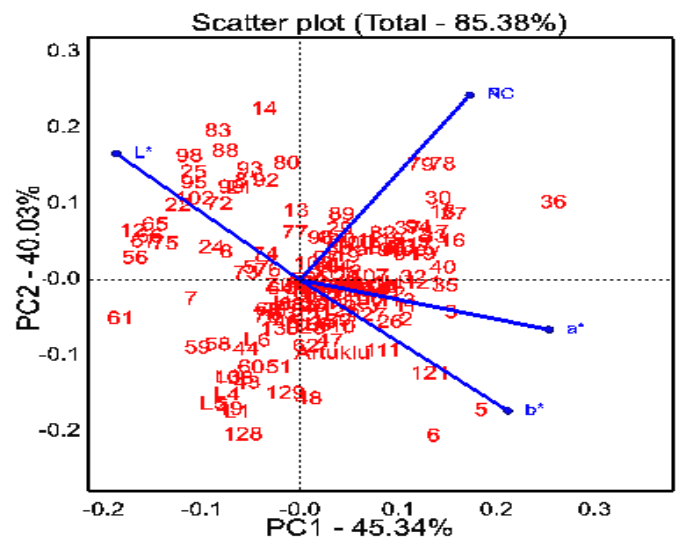

Figure 3. Relation among quality traits and genotypes. (PC: protein content, $N$ : total nitrogen, $L^{*}$ : brightness, $a^{*}:$ redness, $b^{*}$ : yellowness)

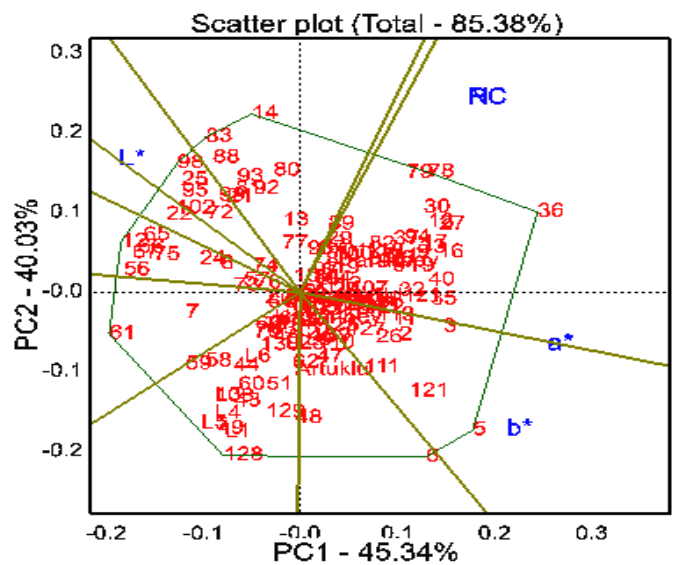

Figure 4. Sectors on genotypes and quality traits. (PC: protein content, $N$ : total nitrogen, $L^{*}$ : brightness, $a^{*}:$ redness, $b^{*}:$ yellowness)

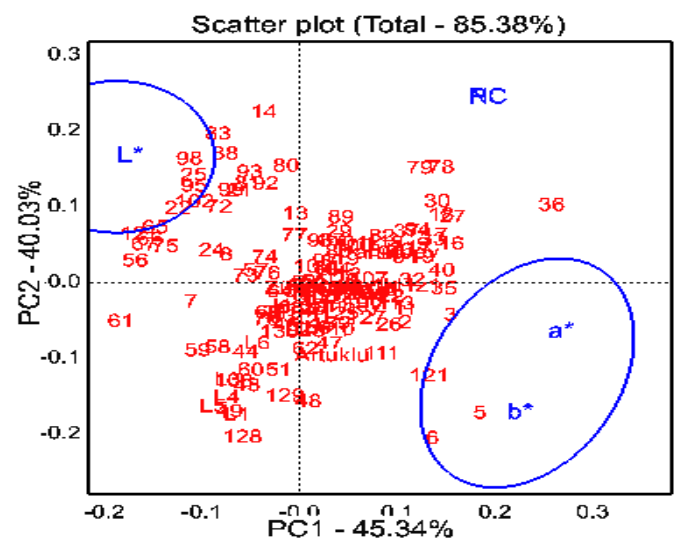

Figure 5. Groups on genotypes and quality traits. (PC: protein content, $N$ : total nitrogen, $L^{*}$ : brightness, $a^{*}:$ redness, $b^{*}:$ yellowness) 


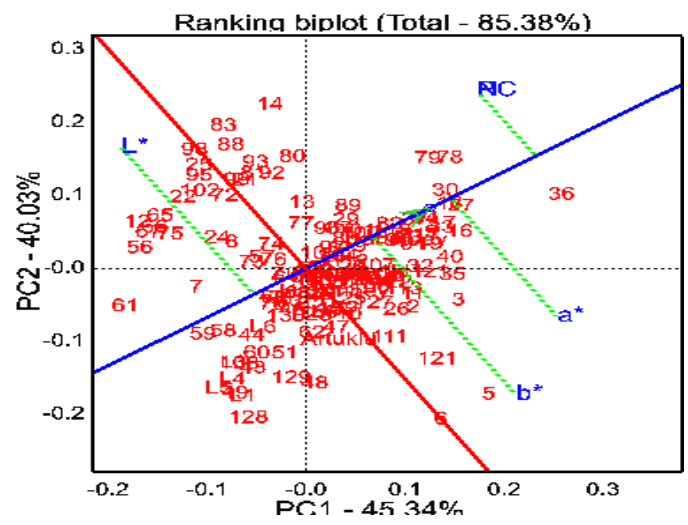

Figure 6. Ranking of genotypes on means of quality traits. (PC: protein content, $N$ : total nitrogen, $L^{*}$ : brightness, $a^{*}:$ redness, $b^{*}:$ yellowness)

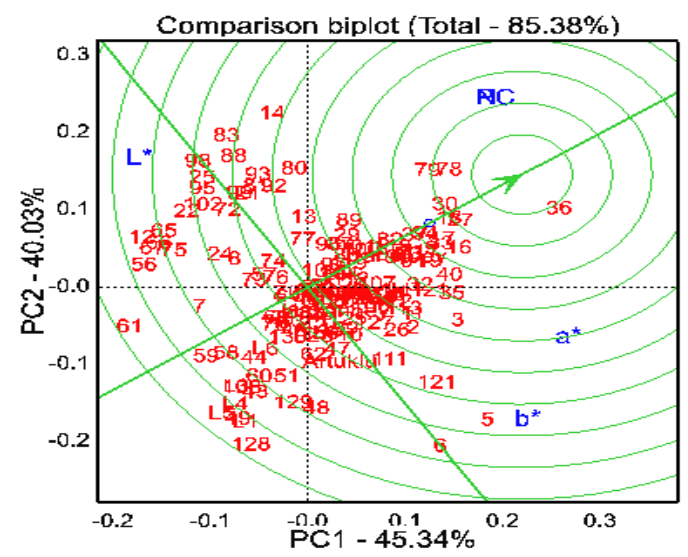

Figure 7. Comparison of genotypes on means of quality traits. (PC: protein content, $N$ : total nitrogen, $L^{*}:$ brightness, $a^{*}:$ redness, $b^{*}$ : yellowness)

\section{Results}

The analysis of augmented (increased) experimental design revealed highly significant differences among the 145 genotypes of durum wheat for total nitrogen percent $(\mathrm{N} \%)$, protein content $\mathrm{L}^{*}($ lightness color of semolina) $(\mathrm{p}<0.05)$, while it was not significant for $\mathrm{a}^{*}$ (represents redness color of semolina) and $\mathrm{b}^{*}$ (represents yellowness color of semolina), as shown in Table 2. Moreover, significant interactions among the tested genotypes indicated that the genotypes had difference genotypic structures in terms of examined quality parameters. Usually, the wheat breeders interested in the landraces with high genotypic main effect (high values than average) and with low fluctuation in examined parameters (stable). The results variance analysis of sum of squares of quality parameters showed in Table 2.

\section{The results of the data reviewed}

The total nitrogen $(\mathrm{N})$ percent of genotypes ranged from $2.07 \%(\mathrm{G} 1)$ to $3.18 \%$ (G79) and the mean of total nitrogen percent of genotypes was found $2.65 \%$ (Table 4). The results of the total nitrogen percent indicated that 79 genotypes have higher values than the five standards used as the control in the study. On the other hand; Güneyyıldizı and 
Zühre varieties were the best on total nitrogen percent of among standards which used in the study. The landraces which collected in same province of Southeastern Anatolia Region showed different performance on total nitrogen percent, but the landraces which collected in Diyarbakır city (Dicle, Hani and Lice province) and Siirt city (Eruh province) had good results of total nitrogen percent respectively. Moreover; the landraces (G59-G64) collected in Gerger province of Adryaman city had low value of total nitrogen percent. The results of total nitrogen percent showed that Southeastern Anatolia Region of Turkey is one of the Centers of origin of durum wheat showed a unique position from the view point of genetic diversity of durum wheat by landraces. Therefore, it is possible to can select the best landraces which have the best results in the study to improve the total of nitrogen and enrich the gene pool and develop quality varieties.

Table 2. The variance analysis of sum of squares of quality parameters

\begin{tabular}{c|c|c|c|c|c|c}
\hline \multirow{2}{*}{ Source } & \multirow{2}{*}{$\mathbf{d f}$} & \multirow{2}{*}{$\mathbf{N}(\boldsymbol{*})$} & \multirow{2}{*}{$\mathbf{P C}(\%)$} & \multicolumn{3}{|c}{ CIE (Semolina color results) } \\
\cline { 5 - 7 } & & & & $\mathbf{L}^{*}$ brightness & $\mathbf{a}^{*}$ redness & $\mathbf{b}^{*}$ yellowness \\
\hline Genotype & 144 & $6.310^{*}$ & $191.467^{*}$ & $842.325^{*}$ & $38.752 \mathrm{~ns}$ & $1125.964 \mathrm{~ns}$ \\
Blok & 6 & 0.452 & 14.698 & 24.438 & 13.038 & 109.694 \\
Model & 150 & 9.230 & 286.832 & 1019.069 & 82.101 & 1339.982 \\
Error & 24 & 0.558 & 18.136 & 67.202 & 5.448376 & 126.678 \\
C Total & 174 & 9.789 & 304.967 & 1086.271 & 87.550 & 1466.66 \\
\hline \multicolumn{2}{c|}{ LSD (0.05) } & 0.360 & 2.071 & 3.959 & 0.621 & 5.436 \\
\hline \multicolumn{2}{c|}{ CV (\%) } & 5.790 & 5.78 & 2.05 & 20.81 & 13.81 \\
\hline
\end{tabular}

LSD: least significant effect, CV: Coefficient of variation, d.f.: degree of freedom *: Value significant at 0.05 probability level, ns: not significant, $\mathrm{N}(\%)$ : total nitrogen, PC (\%): Protein content

The protein content of 145 genotypes varied from $12.22 \%$ (G77) to $18.11 \%$ (G79) and the average of the genotypes was found $15.14 \%$ and nearly 80 genotypes (all of them are landraces) had high value of protein content\% (Table 3). The consequence of protein content showed that more than half of landraces have high protein content results than 5 varieties which used in the study as check. However, Güneyyıldızı and Zühre varieties were the best on protein content of among standards. These two varieties registries (2010) the last time in the region and they are used in farming area, because of high quality parameters. There was diversity on protein content among landraces which collected in same province, but the landraces showed good performance which collected in Şanlıurfa (Siverek) Diyarbakır city (Dicle, Hani and Lice province) and Siirt city (Eruh province) on protein content respectively. Moreover; the landraces (G61-G64) collected in Sincik province of Adryaman city had low value of crude protein content. The outcome of protein content indicated that Centers of Origin of durum wheat (Southeastern Anatolia Region of Turkey) is one of the unique positions from the view point of genetic diversity of durum wheat by landraces. On the other hand the study showed that there is high and positive correlation (Fig. 3) between protein content and total nitrogen percent of genotypes. Range of protein contents defined in this study was in accordance to that reported by Simmonds (1989), reported that average protein content of durum wheat may vary from 9-18\%. Matsuo and Irvine (1970) reported that wheat with $13 \%$ or higher protein content made a satisfactory 
pasta, whereas a protein content lower than $11 \%$ gave a pasta with poor cooking quality. The results of our study showed that majority of landraces had high value of protein content that made a satisfactory pasta $(=$ and $>13 \%)$.

Table 3. The result of correlation analysis among quality parameters

\begin{tabular}{c|c|c|c|c|c}
\hline \multicolumn{2}{c|}{} & N (T. Nitr.) & P. content & L* brightness & a* redness \\
\hline \multirow{2}{*}{$\Xi$} & L* brightness & $0.13 \mathrm{~ns}$ & $-0.25 \mathrm{~ns}$ & & \\
& $\mathrm{a}^{*}$ redness & $0.19 *$ & $0.17 * *$ & $-0.47 * *$ & \\
& $\mathrm{~b}^{*}$ yellowness & $-0.08 \mathrm{~ns}$ & $-0.25 \mathrm{~ns}$ & $-0.58^{* *}$ & $0.69 * *$ \\
\hline
\end{tabular}

**: Value significiant at 0.01 , *: Value significant at 0.05 probability level, ns: not significant, $\mathrm{N} \%$ : total nitrogen

$L^{*}$ value, brightness of semolina color of 145 genotypes ranged from 71.11 (G122) to 89.12 (G13) and the average of the genotypes was found 81.29 value and nearly 30 landraces had high value on CIE $\mathrm{L}^{*}$ brightness of semolina color than the best variety which used in the study as control\% (Table 4). On the other hand, the results demonstrated that Güneyy1ldızı and Zühre varieties were the best on L* brightness of semolina color of among standards. These two varieties released last time, because of high value $\mathrm{L}^{*}$ brightness of semolina color. The results indicated that there is high diversity among local populations collected in the region. Especially, the landraces which collected in the Hani, Lice provinces which located the north of Diyarbakir city where consist of Karacadağ mountain which Centers of Origin of durum wheat were the best among genotypes with regard to $\mathrm{L}^{*}$ semolina color. Furthermore, the first genotypes (landraces) which collected in around Diyarbakır city plain places and the genotypes which collected in Kulp province were very poor on $\mathrm{L}^{*}$ semolina color. The result of study showed that there was high genetic heterogeneity among durum wheat landraces and it can be support to improve genetic pool for breeder of durum wheat.

$a^{*}$ value, redness of semolina color of 145 genotypes varied from 0.35 (G13) to 3.85 (G41) and the average of the genotypes was found 2.32 value. The results indicated that there is high negative correlation $\left(-0.47^{* *}\right)$ between $a^{*}$ redness of semolina color and $\mathrm{L}^{*}$ brightness of semolina color (Table 3 and Fig. 3).

$b^{*}$ value, yellowness of semolina color of 145 genotypes ranged from 6.76 (G13) to 22.13 (G6) and the average of the genotypes was found 16.44 value (Table 4). The results indicated that there is high negative correlation between $b^{*}$ and $L^{*}$ and high positive correlation between $\mathrm{b}^{*}$ and $\mathrm{a}^{*}$ semolina colors (Table 3 and Fig. 3).

\section{Graphically the association between genotypes and quality parameters}

Principal component analysis was used to show the distribution of genotypes based on quality traits. The two dimensional PCA score plot, derived from multi-traits and accounted for $85.38 \%$ (45.34\% and $40.03 \%$ for PC1 and PC2, respectively) of the total variation (Figs. 3-7). The scatter plot showed that three groups were occurred among quality traits and genotypes showed a wide distribution on traits, and also it was showed high correlation between $b^{*}$ jaundice, $\mathrm{a}^{*}$ redness (Fig. 3). The results showed that cultivars and more landraces have general adaptability for all quality parameters (Fig. 4), while some genotypes (79, 78, etc.), (22, 102, etc.), (3..) and 121, 5, etc.) showed specific adaptation for $\mathrm{N}, \mathrm{PC}, \mathrm{L}^{*}, \mathrm{a}^{*}$ and $\mathrm{b}^{*}$ respectively (Figs. 5 and 6 ). 
According to the biplot techniques, G36 came forward with the N, P and $\mathrm{a}^{*}$ and desirable landraces, G5 for $b^{*}, 30$ stable line for all quality parameters, while $(128,61$, etc.) and majority of promising lines (L4, L6) came not forward with any quality parameters (Fig. 7). The study indicated that GT biplot can be used to evaluate the genotypes as graphically to select the best genotypes for parents to use in breeding program (Oral, 2018).

Table 4. The rank and means of the quality parameters of durum wheat genotypes

\begin{tabular}{|c|c|c|c|c|c|c|c|c|c|c|}
\hline \multirow{2}{*}{ Genotype } & \multirow{2}{*}{ Rank } & \multirow{2}{*}{$\mathbf{N}(\%)$} & \multirow{2}{*}{ Rank } & \multirow{2}{*}{$\mathrm{PC}(\%)$} & \multicolumn{6}{|c|}{ CIE (semolina color results) } \\
\hline & & & & & Rank & $\mathbf{L}^{*}$ & Rank & $\mathbf{a}^{*}$ & Rank & $\mathbf{b}^{*}$ \\
\hline 1 & 145 & 2.07 & 65 & 15.38 & 144 & 74.53 & 127 & 1.66 & 126 & 12.08 \\
\hline 2 & 70 & 2.68 & 71 & 15.25 & 142 & 75.25 & 143 & 0.92 & 130 & 11.40 \\
\hline 3 & 52 & 2.74 & 52 & 15.63 & 114 & 79.97 & 96 & 2.14 & 105 & 15.63 \\
\hline 4 & 24 & 2.83 & 24 & 16.15 & 118 & 79.85 & 57 & 2.50 & 99 & 16.91 \\
\hline 5 & 81 & 2.64 & 82 & 15.04 & 28 & 82.91 & 125 & 1.78 & 131 & 11.28 \\
\hline 6 & 83 & 2.64 & 84 & 15.02 & 139 & 76.36 & 86 & 2.23 & 1 & 22.13 \\
\hline 7 & 115 & 2.45 & 116 & 13.98 & 140 & 76.31 & 71 & 2.41 & 10 & 19.48 \\
\hline 8 & 123 & 2.42 & 124 & 13.82 & 18 & 83.86 & 142 & 1.02 & 144 & 7.33 \\
\hline 9 & 87 & 2.62 & 88 & 14.92 & 10 & 85.71 & 141 & 1.20 & 142 & 8.37 \\
\hline 10 & 9 & 3.01 & 9 & 17.15 & 55 & 81.55 & 111 & 2.02 & 112 & 14.45 \\
\hline 11 & 58 & 2.72 & 58 & 15.50 & 20 & 83.70 & 122 & 1.83 & 114 & 14.03 \\
\hline 12 & 50 & 2.75 & 50 & 15.66 & 57 & 81.50 & 64 & 2.44 & 110 & 14.79 \\
\hline 13 & 106 & 2.52 & 107 & 14.36 & 1 & 89.12 & 145 & 0.35 & 145 & 6.76 \\
\hline 14 & 20 & 2.86 & 20 & 16.32 & 11 & 85.49 & 140 & 1.22 & 137 & 10.16 \\
\hline 15 & 3 & 3.13 & 3 & 17.86 & 2 & 88.22 & 144 & 0.49 & 143 & 7.62 \\
\hline 16 & 98 & 2.56 & 99 & 14.62 & 24 & 83.28 & 121 & 1.84 & 115 & 13.96 \\
\hline 17 & 7 & 3.04 & 7 & 17.32 & 90 & 80.80 & 82 & 2.28 & 113 & 14.20 \\
\hline 18 & 6 & 3.04 & 6 & 17.33 & 35 & 82.36 & 105 & 2.08 & 109 & 14.89 \\
\hline 19 & 4 & 3.11 & 4 & 17.74 & 29 & 82.80 & 106 & 2.07 & 111 & 14.67 \\
\hline 20 & 12 & 2.95 & 12 & 16.80 & 34 & 82.37 & 101 & 2.11 & 108 & 15.07 \\
\hline 21 & 107 & 2.51 & 108 & 14.32 & 82 & 81.02 & 38 & 2.69 & 102 & 16.41 \\
\hline 22 & 94 & 2.59 & 95 & 14.79 & 17 & 83.93 & 118 & 1.89 & 140 & 9.65 \\
\hline 23 & 121 & 2.44 & 122 & 13.89 & 12 & 85.39 & 129 & 1.57 & 141 & 9.01 \\
\hline 24 & 64 & 2.70 & 64 & 15.39 & 86 & 80.97 & 14 & 2.94 & 72 & 17.67 \\
\hline 25 & 134 & 2.36 & 135 & 13.45 & 23 & 83.46 & 110 & 2.03 & 138 & 10.15 \\
\hline 26 & 95 & 2.58 & 96 & 14.71 & 6 & 85.85 & 138 & 1.30 & 139 & 9.70 \\
\hline 27 & 113 & 2.46 & 114 & 14.03 & 141 & 76.04 & 11 & 3.00 & 104 & 15.78 \\
\hline 28 & 16 & 2.90 & 16 & 16.55 & 131 & 78.97 & 18 & 2.92 & 83 & 17.43 \\
\hline 29 & 100 & 2.56 & 101 & 14.61 & 128 & 79.08 & 30 & 2.78 & 84 & 17.39 \\
\hline 30 & 79 & 2.66 & 80 & 15.15 & 48 & 81.87 & 78 & 2.34 & 107 & 15.34 \\
\hline 31 & 13 & 2.93 & 13 & 16.68 & 113 & 79.97 & 33 & 2.75 & 93 & 17.11 \\
\hline 32 & 73 & 2.67 & 74 & 15.25 & 102 & 80.47 & 48 & 2.62 & 96 & 16.97 \\
\hline 33 & 85 & 2.63 & 86 & 14.98 & 121 & 79.66 & 8 & 3.05 & 40 & 18.40 \\
\hline 34 & 33 & 2.79 & 33 & 15.93 & 110 & 80.03 & 15 & 2.94 & 45 & 18.32 \\
\hline 35 & 105 & 2.52 & 106 & 14.37 & 96 & 80.62 & 44 & 2.65 & 57 & 17.95 \\
\hline 36 & 75 & 2.67 & 76 & 15.20 & 138 & 76.69 & 6 & 3.18 & 73 & 17.63 \\
\hline
\end{tabular}




\begin{tabular}{|c|c|c|c|c|c|c|c|c|c|}
\hline 37 & 3.09 & 5 & 17.60 & 136 & 78.26 & 2 & 3.80 & 5 & 19.78 \\
\hline 38 & 2.78 & 38 & 15.84 & 104 & 80.44 & 37 & 2.69 & 86 & 17.34 \\
\hline 114 & 2.46 & 115 & 14.03 & 50 & 81.74 & 98 & 2.13 & 92 & 17.16 \\
\hline 129 & 2.39 & 130 & 13.62 & 132 & 78.69 & 65 & 2.44 & 100 & 16.87 \\
\hline 11 & 2.95 & 11 & 16.82 & 45 & 82.00 & 1 & 3.85 & 2 & 20.74 \\
\hline 26 & 2.82 & 26 & 16.10 & 120 & 79.68 & 12 & 2.97 & 14 & 19.24 \\
\hline 89 & 2.61 & 90 & 14.88 & 87 & 80.91 & 56 & 2.50 & 61 & 17.87 \\
\hline 137 & 2.32 & 138 & 13.20 & 69 & 81.25 & 80 & 2.30 & 34 & 18.54 \\
\hline 125 & 2.42 & 126 & 13.80 & 38 & 82.31 & 102 & 2.11 & 43 & 18.36 \\
\hline 97 & 2.57 & 98 & 14.64 & 60 & 81.42 & 79 & 2.33 & 54 & 17.96 \\
\hline 47 & 2.75 & 47 & 15.68 & 76 & 81.07 & 59 & 2.47 & 64 & 17.85 \\
\hline 96 & 2.57 & 97 & 14.67 & 108 & 80.17 & 25 & 2.87 & 22 & 18.76 \\
\hline 133 & 2.36 & 134 & 13.45 & 122 & 79.64 & 17 & 2.92 & 4 & 19.83 \\
\hline 142 & 2.21 & 143 & 12.57 & 49 & 81.83 & 81 & 2.28 & 9 & 19.49 \\
\hline 62 & 2.70 & 62 & 15.41 & 67 & 81.28 & 103 & 2.09 & 81 & 17.46 \\
\hline 126 & 2.42 & 127 & 13.80 & 79 & 81.06 & 72 & 2.38 & 11 & 19.41 \\
\hline 60 & 2.71 & 60 & 15.47 & 70 & 81.17 & 84 & 2.26 & 29 & 18.60 \\
\hline 54 & 2.74 & 54 & 15.60 & 62 & 81.39 & 92 & 2.18 & 89 & 17.23 \\
\hline 45 & 2.76 & 45 & 15.71 & 63 & 81.36 & 89 & 2.19 & 62 & 17.86 \\
\hline 44 & 2.76 & 44 & 15.74 & 61 & 81.41 & 90 & 2.19 & 58 & 17.92 \\
\hline 110 & 2.49 & 111 & 14.22 & 4 & 86.00 & 136 & 1.39 & 128 & 11.68 \\
\hline 66 & 2.69 & 67 & 15.36 & 21 & 83.62 & 126 & 1.77 & 95 & 16.97 \\
\hline 130 & 2.39 & 131 & 13.60 & 40 & 82.10 & 116 & 1.95 & 101 & 16.43 \\
\hline 135 & 2.33 & 136 & 13.29 & 81 & 81.03 & 108 & 2.05 & 116 & 13.72 \\
\hline 141 & 2.22 & 142 & 12.68 & 77 & 81.07 & 62 & 2.44 & 18 & 19.10 \\
\hline 144 & 2.14 & 145 & 12.22 & 16 & 84.34 & 128 & 1.62 & 117 & 13.50 \\
\hline 131 & 2.38 & 132 & 13.55 & 98 & 80.57 & 29 & 2.79 & 3 & 19.95 \\
\hline 116 & 2.45 & 117 & 13.97 & 105 & 80.28 & 76 & 2.35 & 63 & 17.86 \\
\hline 103 & 2.53 & 104 & 14.44 & 53 & 81.66 & 104 & 2.08 & 27 & 18.64 \\
\hline 109 & 2.50 & 110 & 14.23 & 7 & 85.84 & 135 & 1.40 & 121 & 12.90 \\
\hline 117 & 2.45 & 118 & 13.97 & 5 & 85.96 & 133 & 1.41 & 118 & 13.26 \\
\hline 122 & 2.43 & 123 & 13.84 & 9 & 85.72 & 137 & 1.35 & 119 & 13.14 \\
\hline 111 & 2.49 & 112 & 14.21 & 80 & 81.06 & 73 & 2.36 & 24 & 18.70 \\
\hline 118 & 2.44 & 119 & 13.93 & 56 & 81.51 & 94 & 2.16 & 36 & 18.53 \\
\hline 127 & 2.42 & 128 & 13.79 & 66 & 81.33 & 93 & 2.16 & 28 & 18.64 \\
\hline 119 & 2.44 & 120 & 13.93 & 83 & 81.01 & 67 & 2.43 & 76 & 17.56 \\
\hline 77 & 2.66 & 78 & 15.15 & 27 & 82.95 & 117 & 1.95 & 133 & 11.21 \\
\hline 104 & 2.52 & 105 & 14.39 & 30 & 82.75 & 123 & 1.79 & 78 & 17.52 \\
\hline 88 & 2.61 & 89 & 14.89 & 31 & 82.63 & 119 & 1.88 & 85 & 17.35 \\
\hline 120 & 2.44 & 121 & 13.92 & 19 & 83.70 & 124 & 1.79 & 135 & 11.04 \\
\hline 99 & 2.56 & 100 & 14.61 & 42 & 82.03 & 112 & 2.02 & 87 & 17.31 \\
\hline 57 & 2.73 & 57 & 15.56 & 39 & 82.29 & 115 & 1.98 & 80 & 17.48 \\
\hline 1 & 3.18 & 1 & 18.11 & 111 & 80.02 & 26 & 2.87 & 44 & 18.33 \\
\hline 2 & 3.14 & 2 & 17.91 & 99 & 80.53 & 39 & 2.68 & 50 & 18.06 \\
\hline 25 & 2.83 & 25 & 16.13 & 54 & 81.64 & 88 & 2.20 & 132 & 11.24 \\
\hline 61 & 2.71 & 61 & 15.45 & 22 & 83.51 & 113 & 2.00 & 123 & 12.19 \\
\hline
\end{tabular}




\begin{tabular}{|c|c|c|c|c|c|c|c|c|c|c|}
\hline 83 & 36 & 2.78 & 36 & 15.87 & 117 & 79.89 & 22 & 2.90 & 69 & 17.72 \\
\hline 84 & 27 & 2.82 & 27 & 16.10 & 8 & 85.80 & 134 & 1.41 & 127 & 11.82 \\
\hline 85 & 91 & 2.60 & 92 & 14.81 & 94 & 80.68 & 52 & 2.56 & 71 & 17.68 \\
\hline 86 & 112 & 2.49 & 113 & 14.18 & 91 & 80.78 & 46 & 2.64 & 55 & 17.95 \\
\hline 87 & 71 & 2.68 & 72 & 15.25 & 95 & 80.67 & 58 & 2.48 & 60 & 17.89 \\
\hline 88 & 65 & 2.70 & 66 & 15.37 & 75 & 81.13 & 69 & 2.42 & 79 & 17.49 \\
\hline 89 & 40 & 2.78 & 40 & 15.83 & 14 & 85.29 & 132 & 1.51 & 122 & 12.59 \\
\hline 90 & 37 & 2.78 & 37 & 15.85 & 64 & 81.36 & 66 & 2.44 & 97 & 16.97 \\
\hline 91 & 48 & 2.75 & 48 & 15.68 & 126 & 79.38 & 16 & 2.93 & 25 & 18.69 \\
\hline 92 & 42 & 2.77 & 42 & 15.81 & 133 & 78.66 & 19 & 2.91 & 13 & 19.31 \\
\hline 93 & 53 & 2.74 & 53 & 15.62 & 43 & 82.02 & 97 & 2.14 & 129 & 11.43 \\
\hline 94 & 51 & 2.75 & 51 & 15.65 & 26 & 82.99 & 109 & 2.03 & 136 & 11.03 \\
\hline 95 & 21 & 2.86 & 21 & 16.32 & 127 & 79.25 & 7 & 3.11 & 38 & 18.44 \\
\hline 96 & 86 & 2.62 & 87 & 14.93 & 13 & 85.30 & 131 & 1.52 & 124 & 12.16 \\
\hline 97 & 72 & 2.68 & 73 & 15.25 & 59 & 81.43 & 75 & 2.36 & 90 & 17.22 \\
\hline 98 & 90 & 2.61 & 91 & 14.87 & 68 & 81.27 & 42 & 2.66 & 82 & 17.44 \\
\hline 99 & 63 & 2.70 & 63 & 15.40 & 3 & 86.15 & 139 & 1.27 & 125 & 12.12 \\
\hline 100 & 78 & 2.66 & 79 & 15.15 & 25 & 83.23 & 114 & 1.99 & 134 & 11.16 \\
\hline 101 & 15 & 2.91 & 15 & 16.61 & 84 & 81.00 & 41 & 2.67 & 41 & 18.39 \\
\hline 102 & 14 & 2.92 & 14 & 16.63 & 103 & 80.45 & 49 & 2.61 & 75 & 17.60 \\
\hline 103 & 39 & 2.78 & 39 & 15.83 & 15 & 85.24 & 130 & 1.56 & 120 & 13.10 \\
\hline 104 & 35 & 2.78 & 35 & 15.87 & 65 & 81.34 & 63 & 2.44 & 59 & 17.92 \\
\hline 105 & 30 & 2.81 & 30 & 15.99 & 71 & 81.16 & 50 & 2.61 & 31 & 18.59 \\
\hline 106 & 67 & 2.69 & 68 & 15.35 & 101 & 80.51 & 36 & 2.70 & 47 & 18.22 \\
\hline 107 & 46 & 2.75 & 46 & 15.70 & 119 & 79.69 & 10 & 3.01 & 6 & 19.65 \\
\hline 108 & 23 & 2.84 & 23 & 16.17 & 112 & 80.02 & 21 & 2.91 & 8 & 19.53 \\
\hline 109 & 138 & 2.28 & 139 & 13.02 & 89 & 80.88 & 51 & 2.56 & 56 & 17.95 \\
\hline 110 & 55 & 2.73 & 55 & 15.57 & 116 & 79.92 & 40 & 2.68 & 65 & 17.84 \\
\hline 111 & 84 & 2.63 & 85 & 14.98 & 130 & 78.99 & 23 & 2.89 & 16 & 19.16 \\
\hline 112 & 82 & 2.64 & 83 & 15.02 & 143 & 75.08 & 4 & 3.33 & 48 & 18.19 \\
\hline 113 & 28 & 2.81 & 28 & 16.03 & 109 & 80.11 & 43 & 2.66 & 35 & 18.53 \\
\hline 114 & 29 & 2.81 & 29 & 16.00 & 137 & 78.01 & 5 & 3.24 & 7 & 19.62 \\
\hline 115 & 31 & 2.80 & 31 & 15.95 & 129 & 79.03 & 13 & 2.96 & 12 & 19.31 \\
\hline 116 & 68 & 2.69 & 69 & 15.35 & 85 & 80.98 & 60 & 2.47 & 26 & 18.67 \\
\hline 117 & 41 & 2.77 & 41 & 15.81 & 125 & 79.56 & 28 & 2.80 & 39 & 18.41 \\
\hline 118 & 8 & 3.01 & 8 & 17.18 & 134 & 78.50 & 9 & 3.03 & 20 & 18.92 \\
\hline 119 & 10 & 2.99 & 10 & 17.03 & 135 & 78.47 & 32 & 2.77 & 77 & 17.56 \\
\hline 120 & 18 & 2.87 & 18 & 16.38 & 124 & 79.56 & 77 & 2.35 & 51 & 18.04 \\
\hline 121 & 32 & 2.80 & 32 & 15.93 & 74 & 81.13 & 61 & 2.46 & 74 & 17.60 \\
\hline 122 & 56 & 2.73 & 56 & 15.56 & 145 & 71.11 & 3 & 3.44 & 106 & 15.42 \\
\hline 123 & 17 & 2.89 & 17 & 16.47 & 123 & 79.57 & 27 & 2.86 & 32 & 18.58 \\
\hline 124 & 22 & 2.84 & 22 & 16.20 & 97 & 80.58 & 47 & 2.62 & 53 & 18.02 \\
\hline 125 & 19 & 2.86 & 19 & 16.32 & 106 & 80.26 & 24 & 2.88 & 70 & 17.68 \\
\hline 126 & 49 & 2.75 & 49 & 15.67 & 88 & 80.90 & 31 & 2.78 & 52 & 18.03 \\
\hline 127 & 59 & 2.72 & 59 & 15.49 & 73 & 81.15 & 68 & 2.43 & 98 & 16.96 \\
\hline 128 & 34 & 2.79 & 34 & 15.88 & 107 & 80.18 & 20 & 2.91 & 19 & 18.97 \\
\hline
\end{tabular}




\begin{tabular}{c|c|c|c|c|c|c|c|c|c|c}
129 & 143 & 2.20 & 144 & 12.53 & 92 & 80.71 & 35 & 2.71 & 46 & 18.29 \\
130 & 128 & 2.41 & 129 & 13.71 & 115 & 79.97 & 34 & 2.72 & 49 & 18.16 \\
131 & 92 & 2.60 & 93 & 14.79 & 52 & 81.71 & 70 & 2.41 & 94 & 17.03 \\
132 & 139 & 2.28 & 140 & 12.97 & 46 & 81.96 & 55 & 2.52 & 17 & 19.12 \\
133 & 76 & 2.67 & 77 & 15.19 & 93 & 80.68 & 85 & 2.23 & 42 & 18.39 \\
134 & 132 & 2.37 & 133 & 13.52 & 47 & 81.90 & 83 & 2.27 & 88 & 17.30 \\
135 & 136 & 2.33 & 137 & 13.27 & 37 & 82.34 & 95 & 2.14 & 15 & 19.21 \\
136 & 140 & 2.27 & 141 & 12.93 & 36 & 82.34 & 87 & 2.21 & 37 & 18.48 \\
137 & 102 & 2.54 & 103 & 14.50 & 41 & 82.08 & 91 & 2.18 & 66 & 17.81 \\
138 & 43 & 2.77 & 43 & 15.76 & 58 & 81.46 & 74 & 2.36 & 21 & 18.90 \\
139 & 74 & 2.67 & 75 & 15.22 & 78 & 81.07 & 53 & 2.55 & 33 & 18.58 \\
140 & 69 & 2.69 & 70 & 15.32 & 72 & 81.16 & 45 & 2.64 & 30 & 18.60 \\
\hline Artuklu & 124 & $\mathbf{2 . 4 2}$ & 125 & $\mathbf{1 3 . 8 1}$ & 100 & $\mathbf{8 0 . 5 2}$ & 54 & $\mathbf{2 . 5 3}$ & 23 & $\mathbf{1 8 . 7 1}$ \\
Güneyyıldız1 & 80 & $\mathbf{2 . 6 4}$ & 81 & $\mathbf{1 5 . 0 4}$ & 33 & $\mathbf{8 2 . 3 8}$ & 100 & $\mathbf{2 . 1 2}$ & 67 & $\mathbf{1 7 . 8 0}$ \\
Hasanbey & 101 & $\mathbf{2 . 5 6}$ & 102 & $\mathbf{1 4 . 5 7}$ & 51 & $\mathbf{8 1 . 7 3}$ & 99 & $\mathbf{2 . 1 2}$ & 68 & $\mathbf{1 7 . 7 4}$ \\
Şahinbey & 108 & $\mathbf{2 . 5 0}$ & 109 & $\mathbf{1 4 . 2 6}$ & 44 & $\mathbf{8 2 . 0 0}$ & 107 & $\mathbf{2 . 0 5}$ & 103 & $\mathbf{1 6 . 3 4}$ \\
Zühre & 93 & $\mathbf{2 . 5 9}$ & 94 & $\mathbf{1 4 . 7 9}$ & 32 & $\mathbf{8 2 . 4 7}$ & 120 & $\mathbf{1 . 8 6}$ & 91 & $\mathbf{1 7 . 2 0}$ \\
Mean & & $\mathbf{2 . 6 5}$ & & $\mathbf{1 5 . 1 4}$ & & $\mathbf{8 1 . 2 9}$ & & $\mathbf{2 . 3 2}$ & & $\mathbf{1 6 . 4 4}$ \\
Min. & & $\mathbf{2 . 0 7}$ & & $\mathbf{1 2 . 2 2}$ & & $\mathbf{7 1 . 1 1}$ & & $\mathbf{0 . 3 5}$ & & $\mathbf{6 . 7 6}$ \\
Max. & & $\mathbf{3 . 1 8}$ & & $\mathbf{1 8 . 1 1}$ & & $\mathbf{8 9 . 1 2}$ & & $\mathbf{3 . 8 5}$ & & $\mathbf{2 2 . 1 3}$ \\
\hline
\end{tabular}

$\mathrm{L}^{*}$ : brightness, $\mathrm{a}^{*}$ : Redness, $\mathrm{b}$ *: yellowness, $\mathrm{N} \%$ : total nitrogen, PC: protein content

\section{Discussion}

Nowadays, a number of study have focused on nutrient shortcoming in people who are fed from durum wheat product and to improve the quality of new varieties which came from hybrids made genetic resources in successful breeding programs (Akcura, 2011; Aktas, 2016; Mohammed et al., 2011; Pandey et al., 2016; Kendal and Sener, 2016). For this purposes the durum wheat landraces is very important and these days, they have been largely replaced, in their centers of diversity by monocultures of pure genotypes. This genetic erosion resulted in significant loss of valuable genetic diversity for quality traits (Jaradat, 2013). To improve the quality of new durum varieties, landraces keeps its importance inside genetic diversity in Middle east and Southeastern Anatolia region. Because landraces have adequate quality characteristics for the development of new varieties that can be used in the pasta and bulgur industries. For this reason, durum wheat breeders have recently given more importance to the durum wheat landraces in order to raise the quality criteria in durum wheat (Tekdal et al., 2014; Kilic et al., 2012).

The genotypes used in the research showed high variability in the maintenance of all the quality parameters examined. The still prefer of some wheat landraces shows that they have more competitive advantage on quality parameters relative to modern varieties and it is very imported that modern durum wheat cultivars are superior among cereals to providing high quality protein for billions of people around the world (Jaradat, 2013). Therefore, the need is urgent to improve nutritive quality (Koshgoftarmanesh et al., 2010). The wide variation of genotypes of durum wheat quality parameters were described by more researchers (Tekdal et al., 2014; Kiliç et al., 2012; Kendal and Sener, 2016). The researchers working on durum wheat in different 
years and places have provided some results in support of our study on the quality of durum wheat. To summarize of these studies; as in most grain quality traits in wheat, protein content is known to be affected by genetic and environment mainly location (Bement et al., 2003). However, durum wheat is richer in protein, as this is crucial for pasta making (Nuttal et al., 2017), in Mediterranean areas, durum wheat has a significantly higher average grain $\mathrm{N}$ concentration under the same climatic conditions (Cossani et al., 2011). As a result of the study, grain color and protein content that are durum wheat quality traits were related with bulgur quality properties. Therefore both quality properties can be used indirect selection criterion to develop high quality bulgur genotypes (Tekdal et al., 2014). Durum wheat is a good source of protein and grain protein content of $13 \%$ for durum is a standard in quality throughout the grain industry (Riley et al., 1998). On the other hand; in the pasta industry, high protein content are required to process semolina into a suitable final product because the protein content is responsible for the cooking quality of pasta products (Reddecliffe, 2001). Durum wheat is used in bulgur sector, because it has bright yellow color and contains more protein than other wheat varieties (Bayram, 2000).

Color content has to be increased to avoid artificial coloration, which is reported to be a major problem for pasta and bulgur consumers and industrialists with pasta wheat breeding programs (Schulthess, 2013). In recent years, efforts to obtain yellow bulgur and pasta in the direction of consumers' demands mechanical annealing operations were introduced (Oner, 2002). The color of pasta and bulgur is a result of the relative proportions of pigments in the wheat grain. The color of durum wheat and flour came from the carotenoid pigments (Reddecliffe, 2001). The color of pasta and bulgur is the most important factor that consumers associate with quality and consumers believe that pasta and bulgur with a golden appearance has higher quality than sallow pasta. High yellow pigment content is desirable to ensure that the pasta has an intense amber color (Clarke et al., 1998; Tekdal et al., 2014). The L* value gives an idea of the yellow color and value the brightness of the product in durum wheat, and is considered as an important quality criterion (Sahin et al., 2006). Genotypes with high $b^{*}$ and $\mathrm{L}^{*}$ values indicate that the quality of durum wheat increases and studies have shown that the yellow $b^{*}$ value is $86.6 \%$ and the $\mathrm{L}^{*}$ value is under the genotype effect of $12.6 \%$ (Coşkun et al., 2010; Hailu and Mereker, 2008). Yellow pigment concentration in durum wheat is determining particularly in the commercial and nutritional quality of end-products and very important criterion in the assessment of semolina quality (Digesu et al., 2009). The semolina yellow pigment concentration is defining factor for amber color of the commercial value of durum wheat pasta (Blanco et al., 2011). Pasta quality was assessed by determining color ( $\mathrm{L}^{*}, \mathrm{a}^{*}$ and $\mathrm{b}^{*}$ values) furosine, and quaking quality (stickiness, bulkiness, firmness (Marconi et al., 2002). The colour relationship between wheat fractions were that in all groups, the flour colour values (CIE L*, $\left.a^{*}, b^{*}\right)$ were well defined by those of the whole-meal fraction, and this was attributed to the predominance of the flour fraction in the wheat grain. It is, therefore, possible to extrapolate colour values from the easily accessible, whole-meal samples, to those of the flour fraction, which is the main portion consumed (Humphires et al., 2004).

Principal component analysis (GT Biplot) graphically showed that there is high correlation between genotypes and quality parameters and also relation among quality parameters (Figs. 3-7). The GT biplot mainly allows the visualization of any crossover GT interaction, which is very important for the breeding program (Goyal et al., 2011; Kendal and Sener, 2015; Sayar and Han, 2015). The GT (genotype-trait) biplot provides 
an excellent tool for visualizing genotype $\times$ trait data (Adjabi et al., 2014). In the biplot, a vector was drawn from the biplot centered to each marker of the traits to facilitate visualization of the relationships between genotypes and traits, and the angle of vectors among traits. If the angle of the vector was less than $90^{\circ}$, there was a positive correlation between genotypes and traits. If the angle was equal to $90^{\circ}$, they were not correlated. There was a negative correlation if the angle was less than $90^{\circ}$ (Yan and Kang, 2003). In this study, there was a positive correlation between CIE $\mathrm{a}^{*}$ and CIE $\mathrm{b}^{*}$, and total $\mathrm{N}$ and $\mathrm{PC}$, while negative correlations among CIE $\mathrm{a}^{*}, \mathrm{~b}^{*}$ and $\mathrm{L}^{*}$ (Fig. 3 and Table 3). Nuttall et al. (2017) reported that there is linear correlation between total nitrogen and protein content, Tekdal et al. (2014) reported that there is negative correlation between CIE L* and CIE $\mathrm{a}^{*}$ values and positive correlation between CIE $\mathrm{a}^{*}$ and CIE $b^{*}$ values. On the other hand, there was high and special correlation among some genotype and quality traits. We can select the G6, G5 and G121 for CIE b* and G3 for b* and G25, G98 for L*and G78, G79 for total N and PC (Fig. 4). Kendal et al. (2016), The GGE biplot also ranks the traits for their ability to discriminate among genotypes. Sectors of the biplot formed COI groups based on the winning genotypes in each group of traits. So in the study, the features which examined were in four sectors and located in three different mega-traits. CIE a*, CIE b* located in sector 1 and total $\mathrm{N}$ and PC located in sector 2, while CIE L* only located in sector 3 (Fig. 5). On the other hand, CIE $a^{*}, \mathrm{CIE} \mathrm{b*}$ located in group 1 and CIE $\mathrm{L}^{*}$ only located in group 2, total $\mathrm{N}$ and PC located in group 3 (Fig. 5). The GT biplot method provides considerable flexibility, allowing plant breeders to simultaneously select genotypes for quality and stability (Sabaghnia et al., 2013). Haile et al. (2007), the main goals of breeding programs is one of that producing durum wheat genotypes with high and stable grain protein content in Principal component analysis. In the study showed that G30 is stable genotype for all quality parameters, while G5, G14, G61 and majority of other genotypes were not stable for quality parameters (Fig. 6). Yan and Tinker (2006), the GGE biplot was accurate in interpreting the comparing genotypes and traits. The genotype with both high mean performance and high stability for all of the traits was called an ideal genotype (Kendal and Sayar, 2016; Karaman, 2019). Therefore the center of the concentric circles (i.e., ideal genotype) was the AEA in the positive direction. Genotypes located closer to the ideal genotype were more desirable than others. In the study, G36 located the center of ideal circle, it means that this genotype is ideal and desirable for all quality parameters (Fig. 7). On the other hand, G61 and G128 located under means line and far from center of circle, it means that these genotype are undesirable for all parameters. The results of the study indicated that majority of landraces can be used as parents to improve the quality of durum wheat varieties.

\section{Conclusion}

The study showed that durum wheat landraces still is very importance to raise the quality criteria in durum wheat for breeding programs. The results showed that cultivars and more landraces have general adaptability for all quality parameters, while some genotypes showed special adaptation and G79, G78, for N and PC, G22, G102 for L*, G3 for $\mathrm{a}^{*}$ and G121, G5 for $\mathrm{b}^{*}$. Moreover, G30 was stable and G36 was ideal for all quality parameters. According to the biplot techniques indicated that there is high correlation between CIE $\mathrm{a}^{*}$ value and CIE $\mathrm{b}^{*}$ value and between $\mathrm{N}$ and $\mathrm{PC}$, while negative correlation with these traits to CIE $\mathrm{L}^{*}$ Therefore the study showed that 
majority of landraces can be used as parents to improve the quality of durum wheat varieties on special or general quality parameters.

Acknowledgements. This research was supported by Mardin Artuklu University (MAU-BAP-17KMYO-15). We want thanks to GAP International Agricultural Research Center, Department of wheat breeding program and Karamanoğlu Mehmetbey University, Department Engineering of Food for project contributions and support.

\section{REFERENCES}

[1] Adjabi, A., Bouzerzour, A., Benmahammed, A. (2014): Stability analysis of durum wheat (Triticum durum desf.). - Grain Yield J. of Agr. 13(3): 131-139.

[2] Akçura, M. (2011): The relationships of some traits in Turkish winter bread wheat landraces. - Turkish Journal Agriculture 35(2): 115-125.

[3] Aktaş, H. (2016). Drought tolerance indices of selected landraces and bread wheat (Triticum aestivum L.) genotypes derived from synthetic wheats. - Applied Ecology and Environmental Research 14(4): 177-189.

[4] Bayram, M. (2000): Bulgur around the world. - Cereal Foods World 45(2): 80-82.

[5] Bement, G., Ameha, Y., Alemayehu, Z., Jemanesh, K., Tekalign, T., Bekele, M. (2003): Fertilizer $\mathrm{N}$ effects on yield and grain quality of durum wheat. - Trop. Agric. (Trinidad) 80: 146-151.

[6] Blanco, A., Colasuonno, P., Gadaleta, A., Mangini, G., Schiavulli, A., Simeone, R., Digesù, A. M., Vita, P. D., Mastrangelo, A. M., Cattivelli, L. (2011): Quantitative trait loci for yellow pigment concentration and individual carotenoid compounds in durum wheat. - Journal of Cereal Science 54: 255-264.

[7] Clarke, J. M., Marchylo, B. A., Kovacs, M. I. P., Noll, J. S., McCaig, T. N., Howes, N. K. (1998): Breeding Durum Wheat for Pasta Quality in Canada. - In: Braun, H. J., Altay, F., Kronstad, W. E., Beniwal, S. P. S., McNab, A. (eds.) Wheat: Prospects for Global Improvements. -Kluwer Academic Publishers, Boston, pp. 229-236.

[8] Cossani, C. M., Slafer, G. A., Savin, R. (2011): Do barley and wheat (bread and durum) differ in grain weight stability through seasons and water-nitrogen treatments in a Mediterranean location? - Field Crops Research 121: 240-247.

[9] Digesu, A. M., Platani, C., Cattivelli, L., Mangini, G., Blanco, A. (2009): Genetic variability in yellow pigment components in cultivated and wild tetraploid wheats. Journal of Cereal Science 50: 210-218.

[10] Erdal, I., Küçükyumuk, Z., Kurt, S. S, Değirmenci, M. (2017): Effects of seed weights on plant growth and mineral nutrition of wheat and bean plants. - Suleyman Demirel University, Journal of Natural and Applied Sciences 21(3): 749-755.

[11] FAOSTAT (2013): http://faostat.fao.org/. - FAO, Rome.

[12] Goyal, A., Beres, B. L., Randhawa, H. S., Navabi, A., Salmon, D. F., Eudes, F. (2011): Yield stability analysis of broadly adaptive triticale germplasm in southern and central Alberta. - Canadian J. Plant Sci. 91: 125-135.

[13] Haile, J. K., Sarial, A. K., Assefa, S. (2007): AMMI analysis for stability and locations effect on grain protein content of durum wheat genotypes. - Cereal Research Communications 35(4): 1661-1673.

[14] Hailu, F., Mereker, A. (2008): Variation in gluten strength yellow pigment in Etiopian tetraplaid wheat germplasm. - Genetic Resources and Crop Evolution 55: 277-285.

[15] Humphries, J. M., Graham, R. D., Mares, D. J. (2004): Application of reflectance colour measurement to the estimation of carotene and lutein content in wheat and triticale. Journal of Cereal Science 40(2): 151-159. 
[16] Jaradat, A. A. (2013): Wheat landraces: wheat landraces: a mini review. - Emir. J. Food Agric. 25(1): 20-29.

[17] Karaman, M. (2019). Evaluation of bread wheat genotypes in irrigated and rainfed conditions using biplot analysis. - Applied Ecology and Environmental Research 17(1): 1431-1450.

[18] Kendal, E., Sayar, M. S. (2016): The stability of some spring triticale genotypes using biplot analysis. - The Journal of Animal \& Plant Sciences 26(3): 754-765.

[19] Kendal, E., Sener, O. (2015): Examination of genotype $\times$ environment interactions by GGE biplot analysis in spring durum wheat. - Indian J. Gen. \& Plant Breed. 75(3): 341348.

[20] Kendal, E., Sayar, M. S., Tekdal, S., Aktas, H., Karaman, M. (2016): Assessment of the impact of ecological factors on yield and quality parameters in triticale using GGE biplot and AMMI analysis. - Pak. J. Bot 48(5): 1903-1913.

[21] Kilic, H., Tekdal, S., Kendal, E., Aktas, H. (2012): Evaluation of advanced triticum wheat (Triticum turgidum ssp durum) Lines based on augmented trial design with biplot analysis method. - Kahramanmaras Sutcu Imam University, Natural Science Journal 15(4): 18-25.

[22] Marconi, E., Carcea, M., Schivone, M., Cubadda, R. (2002): Spelt (Triticum spelta L.) pasta quality: Combined effect of flour properties and drying conditions. - Cereal Chemistry 79(5): 634.

[23] Matsuo, R. R., Irvine, G. N. (1970): Effect of gluten on the cooking quality of spaghetti. Cereal Chemistry 47: 173-176.

[24] Mohammed, A., Geremew, B., Amsalu, A. (2011): Variation and associations of quality in ethiopian durum wheat (Triticum turgidum L. var. durum) genotypes. - International Journal Breeding and Genetics. DOI: 1039223/ijpbg.2011.

[25] Morgounov, A., Keser, M., Kan, M., Küçükçongar, M., Özdemir, F., N Gummadov., Muminjanov, H., Zuev, E., Qualset, C. O. (2016): Wheat landraces currently grown in Turkey: distribution, diversity and use. - Crop Sci. 56: 3112-3124.

[26] Nuttall, J. G., O’Leary, G. J., Panozzo, J. F., Walker, C. K., Barlow, K. M., Fitzgerald, G. J. (2017). Models of grain quality in wheat - a review. - Field Crops Research 202: 136145.

[27] Oner, M. D. (2002): Bulgur industry, problems and solution proposal. - Grain Products Technology Congress and Exhibition, Gaziantep, Turkey, pp.39-48.

[28] Oral, E. (2018): Effect of nitrogen fertilization levels on grain yield and yield components in triticale based on AMMI and GGE biplot analysis. - Applied Ecology and Environmental Research 16(4): 4865-4878.

[29] Pandey, A., Khan, M. K., Hakki, E. E., Thomas, G., Hamurcu, M., Gezgin, S., Gizlenci, O., Akkaya, A. S. (2016): Assessment of genetic variability for grain nutrients from diverse regions: potential for wheat improvement. - SpringerPlus 5: 1912.

[30] Reddecliffe, T. M. (2001): Optimizing durum wheat yield and quality. - Master of Science Digital Thesis, Lincoln University, Lincoln New Zealand.

[31] Riley, E. A., Thompson, T. L., White, S. A., Ottman, M. J. (1998): Late Season Tissue Tests for Critical grain Protein Content in Durum, Maricopa. - In: Ottman, M. (ed.) Forage and Grain. A college of Agriculture Report Series. University of Arizona, Tucson, Arizona, pp. 43-50.

[32] Sabaghnia, N., Karimizadeh, R., Mohammadi, M. (2013): GGL biplot analysis of durum wheat yield in multi-environment trials. - Bulgarian J. Agri. Sci. 19(4): 756-765.

[33] Sahin, M., Akcura, M., Gocmen, Aydogan, S. (2006): Assessment of parameters measured by color spectrophotometer in durum wheat breeding. - Botanical Research Journal 2: 17-21.

[34] Sayar, M. S., Han, Y. (2015): Determination of seed yield and yield components of grass pea (Lathyrus sativus L.) lines and evaluations using GGE biplot analysis method. Tarım Bilimleri Dergisi- J. Agri. Sci. 21(1): 78-92. 
[35] Simmonds, D. H. (1989): Inherent Quality Factors in Wheat. Wheat and Wheat Quality in Australia. - CSIRO, Australia, pp. 31-61.

[36] Stehno, Z. (2000): Evaluation of Durum Wheat in the Czech Gene Bank: Quality Parameters. - In: Royo, C., Nachit, M., Di Fonzo, N., Araus, J. L. (eds.) Durum Wheat Improvement in the Mediterranean Region: New Challenges. CIHEAM, Zaragoza, pp. 173-176.

[37] Tekdal, S., Kendal, E., Aktas, H., Ayana, B., Bayram, M., Kilic, H., Yildirim, M. (2014): Status Screening of Wheat Varieties With Some of the Lines in the Local Population and Advanced Level Results in Terms of Quality in Turkey. - TUBITAK-1001, Project No: 1110246.

[38] Velu, G., Ortiz-Monasterio, I., Cakmak, I., Hao, Y., Singh, R. P. (2014): Biofortification strategies to increase grain zinc and iron concentrations in wheat. - J Cereal Sci 59(3): 365-372.

[39] Yan, W., Kang, M. S. (2003): GGE Biplot Analysis: A graphical Tool for Breeders, Geneticists and Agronomists. - CRC Press, Boca Raton. 